\title{
Dust exposure and health of workers in duck hatcheries
}

\author{
Guillam Marie-Thérèse ${ }^{1}$, Martin Sylvie', Le Guelennec Marine', Puterflam Julie' ${ }^{2,3}$, \\ Le Bouquin Sophie ${ }^{3,4}$, Huneau-Salaün Adeline ${ }^{3,4}$ \\ 1 SEPIA-Sante, 31 rue de Pontivy, 56150 Baud, France \\ 2 ITAVI, 41 rue de Beaucemaine, 22440 Ploufragan, France \\ ${ }^{3}$ Sanivol, Zoopôle Beaucemaine, 22440 Ploufragan, France \\ ${ }^{4}$ ANSES - Ploufragan-Plouzané Laboratory, BP 53, 22440 Ploufragan, France
}

Guillam MT, Martin S, Le Guelennec M, Puterflam J, Le Bouquin S, Huneau-Salaün A. Dust exposure and health of workers in duck hatcheries. Ann Agric Environ Med. 2017; 24(3): 360-365. doi: 10.26444/aaem/75670

\section{Abstract}

Objectives. The objectives of this cross-sectional study were to investigate dust exposure and respiratory health of workers in duck hatcheries in western France.

Method. Ninety volunteer workers, who work in sorting rooms and/or incubation rooms, participated in exposure assessments and medical examinations. Medical examinations were performed by occupational health practitioners. They filled-in a questionnaire with the workers, followed by a lung function test on each worker. General characteristics and prevalence of chronic respiratory symptoms were described in each type of working rooms. Associations between symptoms and exposure (working room or dust level) were studied in GEE multivariate models.

Results. Overall prevalence of chronic respiratory symptoms (cough, phlegm) and chronic bronchitis were similar or lower than in the reference population. However, prevalence of these symptoms was higher for those working in sorting rooms, that were associated with an increased risk of respiratory symptoms and decreased lung function. Respirable dust was also significantly associated with an increased risk of respiratory symptoms. The prevalence of asthma and rhinitis were well above those in the reference population, but did not vary among working rooms. Descriptive data suggested an occupational origin for some cases.

Conclusion. Hatchery workers were at increased risk of compromised respiratory health due to dust exposure, particularly those who work in sorting rooms. Asthma and rhinitis were in excess in this population of workers. Thorough clinical examination of these workers should be performed and all exposures assessed.

\section{Key words}

occupational exposure, hatchery, organic dust, asthma, allergic rhinitis

\section{INTRODUCTION}

Today, exposure to organic dust and its impact on workers' health are well-known on animal production farms $[1,2,3$, $4,5]$. Organic dust contains high levels of bacteria, fungi, and associated substances, such as endotoxins, allergens, peptidoglycans, mycotoxins, etc. Endotoxins have been extensively studied. The level and composition of dust varies among agricultural settings [3, 6]. Many studies have been carried out on swine farms, but fewer on poultry farms. In France, 14,000 farm managers and 42,000 farm workers work in the poultry sector, in direct contact with birds or with poultry products [7]. Among them, farm managers and workers in the hatchery sector (about 6,500 people) are occupationally exposed to bioaerosols due to bird movements or animal handling. Few studies have been published on hatcheries $[8,9,10]$. Furthermore, initial observations indicate that bacterial contaminant concentrations are higher in the air of duck hatcheries than in chicken hatcheries [11, 12], although these studies were limited to a single premises in Germany and in Bulgaria.

A cross-sectional study was carried out between May - October 2013 in duckling hatcheries located in western

Address for correspondence: Marie-Thérèse Guillam, 31 rue de Pontivy, 56150 Baud, France

E-mail: mtguillam_sepia@orange.fr

Received: 28 November 2016; accepted: 15 May 2017; first published: June 2017
France, which is the leading duck production area in the country. The objectives were to evaluate (1) workers' exposure and identify the associated factors, and (2) the prevalence of chronic respiratory symptoms and allergic disease and their links with exposure.

\section{MATERIALS AND METHOD}

Population. The study was carried out in 14 duck hatcheries in western France which produce an average of 258,000 ducklings per week (range: 54,000-1700,000). A questionnaire was filled-in together with the hatchery managers to describe the hatchery characteristics (production size, ventilation system, cleaning practices, etc.).

Health data. Physicians mandated by the farm's health insurance performed the medical examinations. Of the 93 farm owners and workers, 90 underwent the medical examination (one worker left employment and two were ill at the time of the examination). The examination included a questionnaire (derived from the standardized questionnaire of the European Community Health Respiratory Survey) regarding their socio-economic characteristics, previous professional activities, smoking status, respiratory and skin symptoms, respiratory diseases and lung function tests (all physicians received training and used the same Spirolyser 
10 instrument (FIM Medical)). Lung function (forced vital capacity (FVC), forced expiratory volume in 1 second (FEV1), forced expiratory flow from $25 \%-75 \%$ of the vital capacity $\left(\mathrm{FEF}_{25-75}\right)$ and forced expiratory flow at $50 \%$ of the vital capacity $\left.\left(\mathrm{FEF}_{50}\right)\right)$ was tested by having the workers wear a nose clip in a seated position. According to the American Thoracic Society (ATS) criteria, the highest value among three technically acceptable measurements was chosen. The curves were examined a posteriori and only 49 tests were validated.

The exposure measurements were carried out from June to October 2013, during which 92 workers were monitored. Two main working situations were studied:

1) sorting, sexing and trimming the beak of ducklings in the hatching area;

2) working in the incubation area of the hatcheries without direct contact with ducklings.

The personal exposure of workers to inhalable dust (aerodiameter $<100 \mu \mathrm{m})$ and to respirable dust $(<5 \mu \mathrm{m})$ was measured using two individual air samplers (one for each dust fraction). The workers wore the samplers (CIP 10, TERORA, France) in the breathing zone for three hoursuring their working day. During the period of measurement, the workers in the sorting room sorted an average of 31,400 ducklings $(12,000$ to 55,000$)$; the personnel working in the incubation area handled and candled eggs and carried out cleaning and disinfection operations. The dust sampler was equipped with a pre-weighed filter and the suction pump was operated at a rate of $10 \mathrm{l} / \mathrm{min}$. All exposed filters were dried for 12 hours at $37^{\circ} \mathrm{C}$ and then reweighed (AG 104, Mettler Toledo, Viroflay, France). The results were calculated according to air volume and expressed as $\mathrm{mg} / \mathrm{m}^{3}$.

Statistical methods. The dust concentrations were described as mean and standard deviation.

Associations between qualitative variables were analysed using the Chi-square test or a Fisher's exact test if the Chi-square test assumptions were not met. Associations between quantitative and qualitative variables were tested with Student's $t$-test or the Wilcoxon test (if variables were not normally distributed). Logistic regressions for repeated measures (in each hatchery) (GEE - Generalized Estimating Equations) were used to study associations between symptoms and working rooms and between symptoms and dust level. This GEE model can take into account the autocorrelation between volunteers working in the same hatchery. Independent variables with a significance level of at least 0.25 in univariate analyses were selected for a stepwise multivariate regression analysis. The variables were kept in the stepwise model if their significance levels were at least 0.25 . Interactions between exposure levels and some possible predictor variables were tested and, if significant, entered into the model. All workers $(n=90)$ were included in the logistic model used to study associations between symptoms and working rooms. Workers with a validated lung test $(n=49)$ were included in the linear model for associations between lung function and working rooms. For the modelling of symptoms and dust, volunteers who worked in both sorting and incubation rooms were excluded, leaving 53 workers for this test. Associations between lung function and dust could not be investigated because of insufficient numbers of individuals.
All the statistical analyses were performed with the programmes Excel ${ }^{\circ}$ and SAS v9.2 (SAS Institute Inc., Cary, NC, USA).

\section{RESULTS}

Fourteen of the 15 hatcheries in western France were recruited for the study and 90 workers (3-15 workers per hatchery) volunteered to participate in the exposure measurements and undergo a medical examination. All hatchery workers were employees, their general characteristics are presented in Table 1. Some worked exclusively in sorting rooms (34\%) or in incubation rooms (24\%), whereas others worked alternately in the two types of room. More women than men worked in these hatcheries and women were much more numerous that men in the sorting rooms. Overall, women were on average older than men (Tab. 1), but age was not significantly different between working rooms. The same pattern was observed for smoking habits, with significantly more male smokers, but no statistical differences in smokers between working rooms. Small sample sizes may obscure differences between rooms. The average numbers of years of employment in the current hatchery was relatively high (Tab. 1) given the average age of the workers and this contributed mainly to seniority. As commonly observed, most of these farm workers had lived on a farm or in a rural setting during their childhood.

Table 1. Personal characteristics of the workers

\begin{tabular}{|c|c|c|c|c|}
\hline & Total & $\begin{array}{l}\text { Sorting } \\
\text { rooms }\end{array}$ & $\begin{array}{l}\text { Incubation } \\
\text { rooms }\end{array}$ & $\begin{array}{c}\text { Sorting and } \\
\text { incubation } \\
\text { rooms }\end{array}$ \\
\hline $\mathrm{n}(\%)$ & $90(100)$ & $31(34.4)$ & $22(24.4)$ & $37(41.1)$ \\
\hline \multicolumn{5}{|l|}{ Gender, n (\%) } \\
\hline Female & $56(62.2)$ & $25(80.7)$ & $6(27.3)$ & $25(67.6)$ \\
\hline Male & $34(37.8)$ & $6(19.3)$ & $16(72.7)$ & $12(32.4)$ \\
\hline Age, mean (SD) & $42.8(9.5)$ & $43.2(10.5)$ & $42.6(10.2)$ & $42.6(8.3)$ \\
\hline Female & $44.7(8.7)$ & $43.8(10.3)$ & $48.2(6.8)$ & $44.6(7.4)$ \\
\hline Male & $39.7(1.0)$ & $40.3(11.6)$ & $38.3(8.8)$ & $40.6(10.7)$ \\
\hline \multicolumn{5}{|l|}{ Smoking status, n (\%) } \\
\hline Non-smoker & 44 (48.9) & $18(58.1)$ & $8(36.4)$ & $18(48.7)$ \\
\hline Ex-smoker & $20(22.2)$ & $7(22.6)$ & $5(22.7)$ & $8(21.6)$ \\
\hline Current smoker & $26(28.9)$ & $6(19.4)$ & $9(40.9)$ & $11(29.7)$ \\
\hline $\begin{array}{l}\text { Years worked in } \\
\text { current hatchery, } \\
\text { mean (SD) }\end{array}$ & $14.5(8.9)$ & $13.7(8.1)$ & $16.6(11.5)$ & $14.0(7$ \\
\hline $\begin{array}{l}\text { Total number of years } \\
\text { worked on farm(s), }\end{array}$ & & & & \\
\hline mean (SD) & $16.5(9.4)$ & $16.4(9.2)$ & $17.6(11.6)$ & $16.0(8.1)$ \\
\hline \multicolumn{5}{|l|}{ Childhood, n (\%) } \\
\hline $\begin{array}{l}\text { On a farm } \\
\text { In a rural environment }\end{array}$ & $41(48.2)$ & $10(35.7)$ & $12(54.6)$ & $19(48.2)$ \\
\hline $\begin{array}{l}\text { (not on a farm) } \\
\text { In an urban }\end{array}$ & $35(41.2)$ & $17(60.7)$ & $9(40.9)$ & $9(25.7)$ \\
\hline environment & $9(10.6)$ & $1(4.6)$ & $1(3.6)$ & $7(20.0)$ \\
\hline
\end{tabular}

The prevalence of most chronic respiratory symptoms was between $4 \%-15 \%$, with a very low number of symptoms reported in workers in the incubation rooms. Wheezing and shortness of breath during exercise were reported by $20 \%$ or more, and were again less prevalent in incubation room workers. The prevalence of diagnosed chronic bronchitis was only $3.3 \%$. Five workers had been infected in the past by Chlamydophila psittaci, and the potential link between 
this pathogen and the six other reported serious respiratory disease raised questions. For allergic diseases (asthma, allergic rhinitis, eczema), a high prevalence was reported in all working rooms, but there were no differences between working rooms. Nearly all asthma cases were medicallydiagnosed, and for half of them (52\%), the first crisis occurred during their occupational life. With the exception of fever, more work-related symptoms were reported in the sorting room or sorting/incubation room workers than in incubation room workers. Indices of lung function did not different between working rooms.

Workers handling and sorting ducklings in the sorting room were exposed to higher concentrations of inhalable dust $\left(14.581 \mathrm{mg} / \mathrm{m}^{3}\right.$ vs. $\left.0.452 \pm 0.984 \mathrm{mg} / \mathrm{m}^{3} ; \mathrm{P}<0.001\right)$ and respirable dust $\left(0.469 \pm 0.280 \mathrm{mg} / \mathrm{m}^{3}\right.$ vs. $\left.0.117 \pm 0.116 \mathrm{mg} / \mathrm{m}^{3} ; \mathrm{P}<0.01\right)$ than workers in the incubation rooms (Fig. 1). Regarding inhalable dust, the exposure of sorting room workers was 30 -fold higher than that of workers in incubation rooms, but for respirable dust, the difference was only 4 -fold between the two room types. The respirable fraction in the incubation rooms accounted for about $35 \%$ of the inhalable fraction in contrast with the sorting rooms where the respirable fraction represented less than $5 \%$ of the inhalable dust.

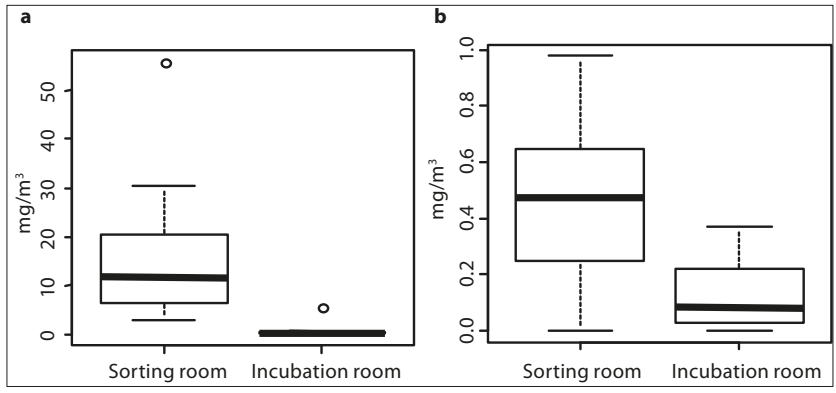

Figure 1. Exposure to inhalable (a) and respirable (b) dust of workers in duck hatcheries during a $3 \mathrm{~h}$ period ( $\mathrm{n}=57$ in sorting room and $\mathrm{n}=35$ in incubation room).

The ventilation systems in the 14 sorting rooms studied were quite similar: forced ventilation system with progressive regulation in 12 rooms (vs. natural ventilation systems in 2 rooms) and equipped with pre-filters at air inlets in only three hatcheries. An aspiration device for fluff was present in the roof above the sorting table of one sorting room. Therefore, the impact of the ventilation system, pre-filters or fluff-collecting system on ambient dust concentration in sorting rooms could not be assessed The mean exposure to inhalable dust was lower when the sorting room was in overpressure $\left(9.705 \pm 4.912 \mathrm{mg} / \mathrm{m}^{3}\right.$ vs. $17.386 \pm 11.100 \mathrm{mg} / \mathrm{m}^{3}$; $\mathrm{p}<0.01)$. In contrast, the exposure to respirable dust was not influenced by the ventilation equipment of the sorting room.

The results of the multivariate models are summarized in Table 3. The risk of suffering from respiratory symptoms (cough and/or phlegm) was significantly higher for individuals working only in sorting rooms or in both types of room, compared with those working exclusively in incubation rooms. The same result was obtained for the work-related respiratory symptoms, but only for the non-allergic workers; this result, however, could not be demonstrated for allergic individuals. Some adjustment variables were independently and significantly associated with increased risk of respiratory symptoms or diseases in these models: the risk of suffering from respiratory symptoms was higher in allergic (asthma, rhinitis or eczema, $\mathrm{p}=0.02$ ) workers; the risk of suffering from
Table 2. Health characteristics of the workers, n (\%)

\begin{tabular}{lcccc}
\hline & Total & $\begin{array}{c}\text { Sorting } \\
\text { rooms }\end{array}$ & $\begin{array}{c}\text { Incubation } \\
\text { rooms }\end{array}$ & $\begin{array}{c}\text { Sorting and } \\
\text { incubation } \\
\text { rooms }\end{array}$ \\
\hline $\begin{array}{l}\text { Respiratory symptoms } \\
\quad \text { Morning cough }\end{array}$ & $11(12.2)$ & $4(12.9)$ & 0 & $7(18.9)$ \\
$\begin{array}{l}\text { Day and/or night } \\
\text { cough }\end{array}$ & $14(15.6)$ & $7(22.6)$ & 0 & $7(18.9)$ \\
$\begin{array}{l}\text { Chronic cough } \\
\text { Morning phlegm }\end{array}$ & $4(4.4)$ & $3(9.7)$ & 0 & $1(2.7)$ \\
$\begin{array}{l}\text { Day and/or night } \\
\text { phlegm }\end{array}$ & $11(12.2)$ & $4(12.9)$ & $2(9.1)$ & $5(13.5)$ \\
$\begin{array}{l}\text { Chronic phlegm } \\
\text { Wheezing }\end{array}$ & $9(10.0)$ & $4(12.9)$ & 0 & $5(13.5)$ \\
$\begin{array}{l}\text { Shortness of breath } \\
\text { at rest }\end{array}$ & $4(5.4)$ & $2(6.5)$ & 0 & $2(5.4)$ \\
$\begin{array}{l}\text { Shortness of breath } \\
\text { during physical } \\
\text { exercise }\end{array}$ & $11(12.2)$ & $3(25.8)$ & $3(13.6)$ & $8(21.6)$ \\
\hline
\end{tabular}

\begin{tabular}{|c|c|c|c|c|}
\hline \multicolumn{5}{|l|}{$\begin{array}{l}\text { Medically-diagnosed } \\
\text { diseases (lifetime) }\end{array}$} \\
\hline Chronic bronchitis & $3(3.3)$ & 1 & 1 & 1 \\
\hline Psittacosis & $5(5.6)$ & 3 & 1 & 1 \\
\hline Pneumonitis & $1(1.1)$ & & & 1 \\
\hline $\begin{array}{l}\text { Serious pulmonary } \\
\text { infection }\end{array}$ & $5(5.6)$ & 1 & 2 & 2 \\
\hline \multicolumn{5}{|l|}{ Asthma } \\
\hline $\begin{array}{l}\text { Ever had asthma } \\
\text { Medically- }\end{array}$ & $22(24.4)$ & $8(25.8)$ & $6(27.3)$ & $8(21.6)$ \\
\hline $\begin{array}{l}\text { diagnosed } \\
\text { asthma }\end{array}$ & $20(95.2)$ & $7(87.5)$ & $5(83.3)$ & $8(100.0)$ \\
\hline First asthma crisis $^{2}$ & & & & \\
\hline childhood & $9(42.9)$ & $3(37.5)$ & $3(50.0)$ & $3(42.9)$ \\
\hline $\begin{array}{l}\text { after } 18 \text {-years-old } \\
\text { when working in }\end{array}$ & $12(57.1)$ & $5(62.5)$ & $3(50.0)$ & $4(57.1)$ \\
\hline hatchery & $11(52.4)$ & $5(62.5)$ & $3(50.0)$ & $3(42.9)$ \\
\hline $\begin{array}{l}\text { Crisis during } \\
\text { the last } 12 \text { years }\end{array}$ & 9 (40.9) & $6(75.0)$ & 0 & $3(37.5)$ \\
\hline Allergic rhinitis & $25(27.8)$ & $8(25.8)$ & $8(36.4)$ & $9(24.3)$ \\
\hline $\begin{array}{l}\text { Eczema and other } \\
\text { atopic dermatitis }\end{array}$ & $22(24.4)$ & $8(25.8)$ & $5(22.7)$ & $9(24.3)$ \\
\hline
\end{tabular}

\section{Work-related}

respiratory symptoms

At least one

respiratory

symptom $\quad 49(54.4) \quad 20(64.5) \quad 8(36.4) \quad 21(56.8)$

Sneezing $\quad 44(48.9) \quad 16(51.6) \quad 6(27.3) \quad 22(59.5)$

Cough $26(28.9) \quad 11(35.5) \quad 6(27.3) \quad 9(24.3)$

$\begin{array}{llll}\text { Fever } & 3(3.3) & 1(3.2) & 1(4.6)\end{array}$

Shortness of

breath $\quad 17(18.9) \quad 8(25.8) \quad 3(13.6) \quad 6(16.2)$

Work-related skin
symptoms

Lung function

(\% of the predicted)

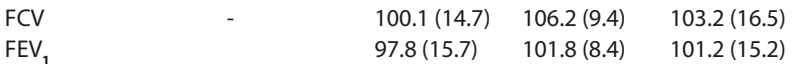

${ }^{1}$ Throughout the day, every day for 3 consecutive months each year.

${ }^{2}$ The first asthma crisis was not described by one worker of the sorting/ incubation group

'occupational' asthma increased with seniority $(\mathrm{p}=0.02)$; the risk of suffering from work-related respiratory symptoms was higher in women $\left(\mathrm{p}<10^{-3}\right)$.

Concerning lung function, working exclusively in sorting rooms was associated with a risk of an 11\% decrease in FVC (forced vital capacity), compared with working in incubation rooms. A decrease was also observed for sorting/incubation room workers, but was borderline significant $(\mathrm{p}=0.12)$. The other lung function index $\left(\mathrm{FEV}_{1}\right)$ was also lower in the sorting room workers, but did not reach the significance 
Table 3. Association between symptoms and exposure

\begin{tabular}{|c|c|c|}
\hline $\begin{array}{l}\text { Model } 1 \text {. Sorting or sorting/incubation } \\
\text { rooms vs. incubation rooms }\end{array}$ & Sorting rooms & $\begin{array}{c}\text { Sorting/ } \\
\text { incubation rooms }\end{array}$ \\
\hline & OR (p-value $)^{1}$ & OR (p-value $)^{1}$ \\
\hline Cough and/or phlegm & $6(0.02)$ & $7.48(0.02)$ \\
\hline Wheezing & $2.68(0.15)$ & $2.50(-)$ \\
\hline Shortness of breath & $1.88(-)$ & $3.28(-)$ \\
\hline $\begin{array}{l}\text { Work-related respiratory symptoms in } \\
\text { allergic workers }{ }^{2}\end{array}$ & $0.34(-)$ & $0.59(-)$ \\
\hline $\begin{array}{l}\text { Work-related respiratory symptoms in } \\
\text { non-allergic workers }{ }^{2}\end{array}$ & $8.45(0.0007)$ & $4.03(0.03)$ \\
\hline \multirow[t]{2}{*}{ Work-related skin symptoms } & $4.20(-)$ & $3.80(0.14)$ \\
\hline & ß (p-value) & B (p-value) \\
\hline FVC & $-10.86(0.001)$ & $-5.59(0.12)$ \\
\hline FEV1 & $-5.22(0.18)$ & $-1.75(-)$ \\
\hline Model 2: Effect of dust & $\begin{array}{l}\text { Inhalable dust } \\
\text { OR (p-value) })^{1,3}\end{array}$ & $\begin{array}{l}\text { Respirable dust } \\
\text { OR (p-value) })^{1,3}\end{array}$ \\
\hline Cough and/or phlegm & $1.0(-)$ & $1.29(0.006)$ \\
\hline Wheezing in allergic workers ${ }^{2}$ & $0.98(-)$ & $0.63(0.003)$ \\
\hline Wheezing in non-allergic workers ${ }^{2}$ & $0.98(-)$ & $1.28(0.009)$ \\
\hline Shortness of breath & $1.02(-)$ & $1.33(0.02)$ \\
\hline Work-related respiratory symptoms & $1.01(-)$ & $0.84(0.19)$ \\
\hline Work-related skin symptoms & $2.79(0.01)$ & $0.29(-)$ \\
\hline
\end{tabular}

1 Odds ratio (OR) adjusted for age, gender, smoking status, number of years worked on a farm and allergic diseases (asthma, rhinitis or eczema). P-value noted if $<0.2$

${ }^{2}$ Significant relationship between allergic diseases and working room.

3 OR values indicate the odds of an association with tested symptom for every increase exposure of $0.1 \mathrm{mg} / \mathrm{m}^{3}$ of inhalable dust and of $0.1 \mu \mathrm{g} / \mathrm{m}^{3}$ of respirable dust.

threshold ( $\mathrm{p}=0.18)$. In these statistical models, seniority was independently associated with the risk of decreased FVC and $\mathrm{FEV}_{1}$. Other lung function indices were also studied in the multivariate analysis: they showed significantly lower $\mathrm{FEF}_{25-75}$ $(\mathrm{p}=0.01)$ and FEF50 $\left(\mathrm{p}<10^{-2}\right)$ in smokers.

Table 3 also gives the results of the model testing the effect of inhalable and respirable dust. An increased risk of work-related skin symptoms was observed for inhalable dust. There were no other associations with inhalable dust. On the other hand, the respirable fraction was associated with all the respirable symptoms, except those work related: it increased the risk of suffering from cough and/or phlegm, from wheezing, but only in non allergic workers, and from shortness of breath. Allergic diseases were independently associated with an increased risk of wheezing in the models for inhalable and respirable dust.

\section{DISCUSSION}

To the best of the authors' knowledge, this study is the first to explore associations between exposure and health in such a large number of hatchery workers.

In France, and in many other European Member States, the Occupational Exposure Limit for inhalable dust is set at $10 \mathrm{mg} / \mathrm{m}^{3}$, on average, for an eight hour working period [13]. In the presented study, 34 of 57 workers sorting ducklings were exposed to inhalable dust higher than this limit value. Therefore, it is absolutely necessary to wear an adequate respiratory mask for tasks that most expose the worker to dust, such as sorting, sexing or beak-trimming ducklings.
Furthermore, current ventilation systems in most hatcheries were clearly not sufficient to prevent high exposure to dust. In particular, maintaining a positive pressure gradient between the sorting room and the outside may be a valuable collective prevention measure.

The overall prevalence of chronic respiratory symptoms (cough, phlegm) appeared to be similar to the general populations in France $[14,15]$. They were also similar to that reported for French and European farming populations $[16,17,18]$. A high prevalence of chronic bronchitis has been reported in other farming populations, such as cattle farmers (10\%) [19].

However, those working exclusively or part-time in sorting rooms (the most dust-exposed rooms) had a higher prevalence of respiratory problems, particularly for day and/ or night cough and for shortness of breath during exercise. This is a cause for concern. Statistical modelling confirmed the risk of suffering from more respiratory symptoms and decreased lung function for sorting room workers. Modelling also confirmed that respirable dust, in excess in sorting rooms, increased the risk of suffering from these symptoms. The effect of organic dust, especially the respirable fraction (which can penetrate deep into the lungs) on respiratory health has already been reported previously [1, 2, 21, 28]. Smoking habits in this population and the French population (29\% of current smokers) were similar [20].

Wheezing, which is a symptom of asthma, was highly prevalent in all workers, regardless of the type of room, and much more prevalent than in other farming populations $[17,21]$. This prevalence matched the prevalence of asthma, including medically-diagnosed asthma cases. Other studies on farm worker populations have not reported any relationship between wheezing and asthma: high wheezing prevalence, but normal to low asthma prevalence [22, 23]. In the current study, asthma prevalence $(22 \%)$ was well above the prevalence in the French population $(6.7 \%)$ or that in the French farm worker population (7.2\%) [16, 24]. It was also well above result from studies in farming [17]. Moreover, half of the asthma cases appeared to be occupational cases. In addition to asthma prevalence, allergic rhinitis prevalence $(28 \%)$ was also higher than in the reference population (18\% in the French population) [25]. Those suffering from rhinitis are at risk of suffering from asthma [26]. Statistical modelling showed that wheezing in asthmatic workers was not associated with dust. Furthermore, allergic diseases (rhinitis, eczema or asthma), used as an adjustment variable in statistical modelling, were generally not associated with exposure (rooms or dust). Other exposures associated with occupational asthma have already been described in farm settings: chemical disinfectants or detergents are known for their irritant and potentially sensitizing properties that affect the respiratory tract or the skin [27, 28]. Likewise, in this study, in addition to the respiratory symptoms, a high prevalence of eczema was also observed. The use of disinfectants is also associated with an increase in chronic respiratory symptoms in pig farmers [29]. Disinfectants are commonly used in hatcheries where cleaning and disinfection are key practices. Therefore, the exposures to these chemicals should be investigated in these hatcheries.

Comparisons of the presented results (health and exposure) with those already described in hatcheries are very difficult due to differences in methodology. A German study demonstrated a decrease in $\mathrm{FEV}_{1}$ for days involving 
duckling sorting, but not for the days without [10]. Although the sample included only four workers, this result suggests that airborne particles from duckling down have a negative effect on respiratory health. In Poland, a study of 32 hatchery workers showed a low prevalence of work-related symptoms and chronic bronchitis, and no decrease in lung function [9]. However, the studied hatcheries were described as modern, well-equipped and with a ventilation system. Furthermore, the duration of employment of most workers was low. Neither asthma nor rhinitis was reported in these two studies.

The current study has several limitations:

1) The cross-sectional design limited the scope of the conclusions. Only volunteer workers from these hatcheries were included, thereby creating a selection bias. Moreover, only the current work stations were noted and some workers may have previously worked in other parts of the hatchery.

2) The sample size was relatively low, especially for some analyses (lung function, multivariate analysis of the effect of dust) where data were not available from all volunteers.

3) There was a preponderance of women in the sample, particularly in the sorting room sample where the highest dust exposure was measured.

Some studies suggest that women in farming are more likely than men to suffer from health problems, such as asthma [27]. Therefore, comparisons with reference populations may be biased. Finally, although the questionnaire was administered by a physician and questions on respiratory and allergic symptoms was based on a standardised questionnaire, the data were nonetheless declarative. Clinical examinations are necessary to better characterize the self-reported diseases, especially asthma, rhinitis and eczema.

\section{CONCLUSION}

Despite some limitations, the study confirmed the negative effects of organic dust on the respiratory health of farm workers, especially those in hatcheries. Data on the prevalence of asthma and rhinitis raise concerns, particularly because they suggest an occupational origin in many cases. Thorough clinical and follow-up examinations of these workers and investigation of other types of exposure can provide further insight into the occupational health risks of duck hatchery workers.

\section{Acknowledgments}

The authors gratefully acknowledge the assistance and cooperation of the following: Dr Ségala and MSA occupational physicians (Drs Bouguer, Chamard-Bois, Camus, Demy, Duteil, Gausseres, Mary, Noizet-Siret, Orhan and Regnier,), the managers and employees of hatcheries and the SNA association (Syndicat National des Accouveurs). The PALMICOUV project was carried out by Sanivol. The authors also thank the French Ministry of Agriculture for funding this research project (CAS DAR 12/1222).

\section{REFERENCES}

1. Donham KJ, Reynolds SJ, Whitten P, Merchant JA, Burmeister L, Popendorf WJ. Respiratory dysfunction in swine production facility workers: dose-response relationships of environmental exposures and pulmonary function. Am J Ind Med. 1995; 27: 405-18. [Crossref]

2. Donham KJ, Cumro D, Reynolds SJ, Merchant JA. Dose-response relationships between occupational aerosol exposures and cross-shift declines of lung function in poultry workers: recommendations for exposure limits. J Occup Environ Med. 2000; 42: 260-9. [Crossref]

3. Radon K, Monso E, Weber C, Danuser B, Iversen M, Opravil U, et al. Prevalence and risk factors for airway diseases in farmers-summary of results of the European farmers'project. Ann Agric Environ Med. 2002; 9: 207-213.

4. Radon K, Danuser B, Iversen M, Monso E, Weber C, Hartung J, et al. Air contaminants in different European farming environments. Ann Agric Environ Med. 2002; 9: 41-8.

5. Eduard W, Pearce N, Douwes J. Chronic bronchitis, COPD, and lung function in farmers: the role of biological agents. Chest. 2009; 136: 716-25. [Crossref]

6. Simpson JC, Niven RM, Pickering CA, Oldham LA, Fletcher AM, Francis HC. Comparative personal exposures to organic dusts and endotoxin. Ann Occup Hyg. 1999; 43: 107-15. [Crossref]

7. MSA, 2007. BIMSA N 76, August September 2007.

8. Tymczyna L, Chmielowiec-Korzeniowska A, Drabik A. The effectiveness of various biofiltration substrates in removing bacteria, endotoxins, and dust from ventilation system exhaust from a chicken hatchery. Poult Sci. 2007; 86: 2095-100. [Crossref]

9. Skórska C, Mackiewicz B, Golec M, Cholewa G, ChmielowiecKorzeniowska A, Dutkiewicz J. Health effects of exposure to organic dust in workers of a modern hatchery. Ann Agric Environ Med. 2007; 14: 341-5.

10. Martin E, Ernst S, Lotz G, Linsel G, Jäckel U. Microbial exposure and respiratory dysfunction in poultry hatchery workers. Environ Sci Process Impacts. 2013; 15: 478-84. [Crossref]

11. Martin E, Jäckel U. Characterisation of bacterial contaminants in the air of a duck hatchery by cultivation based and molecular methods. J Environ Monit. 2011; 13: 464-472. [Crossref]

12. Zhelev G, Lyutzkanov M, Urumova V, Mihaylov G, Petrov V, Marutsov P. Microbial contamination in a duck hatchery. Revue Méd. Vét. 2012; 163: 319-322.

13. OSHA. Occupational Exposure Limits. 2012. Available at: https://www. osha.gov/dts/chemicalsampling/data/CH_259635.html. Accessed on $10 / 23 / 2016$.

14. Huchon G, Vergnenègre A, Neukirch F, Brami G, Roche N, Preux PM. Chronic bronchitis among French adults: high prevalence and underdiagnosis. Eur Respir J. 2002; 20: 806-812. [Crossref]

15. Fuhrman C, Roche N,Vergnenegre A, Chouaid C, Zureik M, Delmas MC. [Bronchite chronique: prévalence et impact sur la vie quotidienne. Analyse des données de l'enquête de santé Insee 2002-2003]. SaintMaurice. Institut de veille sanitaire, février 2008, 37p.

16. Delmas MC, Leynaert B, Ruelle L, Annesi Maesano I, Herbert JB, Fuhrman C. [Asthme: prévalence et impact sur la vie quotidienne. Analyse des données de l'enquête décennale santé 2003 de l'Insee]. Saint- Maurice: Institut de veille sanitaire; 2008, 89p.

17. Radon K, Danuser B, Iversen M, Jörres R, Monso E, Opravil U, et al. Respiratory symptoms in European animal farmers. Eur Respir J. 2001; 17: 747-54. [Crossref]

18. Radon K, Weber C, Iversen M, Danuser B, Pedersen S, Nowak D. Exposure assessment and lung function in pig and poultry farmers. Occup Environ Med. 2001; 58: 405-10. [Crossref]

19. Dalphin JC, Dubiez A, Monnet E, Gora D, Westeel V, Pernet D, et al. Prevalence of asthma and respiratory symptoms in dairy farmers in the French province of the Doubs. Am J Respir Crit Care Med. 1998; 158: 1493-8. [Crossref]

20. Beck F, Guignard R, Richard JB, Wilquin JL, Peretti-Watel P. [Une augmentation du tabagisme confirmée en France]. La Santé de l'homme, INPES. 2011, vol. 411, p 9-10.

21. Guillam MT, Pédrono G, Le Bouquin S, Huneau A, Gaudon J, Leborgne $\mathrm{R}$, et al. Chronic respiratory symptoms of poultry farmers and modelbased estimates of long-term dust exposure. Ann Agric Environ Med. 2013; 20: 307-11.

22. Lembke B, Janson C, Norback D, Rask-Andersen A. High risk of adult-onset asthma and work-related wheeze in farmers despite low prevalence of asthma in young farmers. Int J Tuberc Lung Dis. 2004; 8: 1285-91. 
23. Dalphin JC. [In the agricultural environment there is asthma and asthma... or the paradox of agricultural asthma]. Rev Mal Respir. 2007; 24: 1083-6.

24. Afrite A, Allonier C, Com-Ruelle L, Le Guen N. [L'asthme en France en 2006: prévalence, contrôle et déterminants.] Rapport n ${ }^{\circ} 549,118$ p. IRDES 2011

25. Bauchau V, Durham SR. Prevalence and rate of diagnosis of allergic rhinitis in Europe. Eur Respir J. 2004; 24: 758-64. [Crossref]

26. Ameille J, Hamelin K, Andujar P, Bensefa-Colas L, Bonneterre V. Dupas D, et al. Occupational asthma and occupational rhinitis: the united airways disease model revisited. Occup Environ Med. 2013; 70: 471-5. [Crossref]
27. Omland $\varnothing$. Exposure and respiratory health in farming in temperate zones--a review of the literature. Ann Agric Environ Med. 2002; 9: 119-36.

28. Vogelzang PF, van der Gulden JW, Folgering H, Heederik D, Tielen MJ, van Schayck CP. Longitudinal changes in bronchial responsiveness associated with swine confinement dust exposure. Chest. 2000; 117: 1488-95. [Crossref]

29. Preller L, Heederik D, Boleij JS, Vogelzang PF, Tielen MJ. Lung function and chronic respiratory symptoms of pig farmers: focus on exposure to endotoxins and ammonia and use of disinfectants. Occup Environ Med. 1995; 52: 654-60. [Crossref] 